2. To: (Receiving Organization)

Spent Nuclear Fuel Storage Projects Duke Engineering \& Services

5. Proj/Prog./Dept./Div.:

SNF / K Basin

8. Originator Remarks:

Document attached for approval and release.

3. From: (Originating Organization)

Mechanisms Engineering, Fluor Daniel Northwest

6. Design Authority/Design Agent/Cog. Engr.:

L. H. Goldmann
4. Related EDT No.:

N/A

7. Purchase Order No.:

N/A

9. Equip./Component No.:
11A. Design Baseline Document? [X] Yes [] No
11. Receiver Remarks:
10. System/Bldg./Facility:

$105 \mathrm{KE} / 105 \mathrm{KW}$

12. Major Assm. Dwg. No.:

N/A

13. Permit/Permit Application No::

N/A

14. Required Response Date:

March 21, 1997

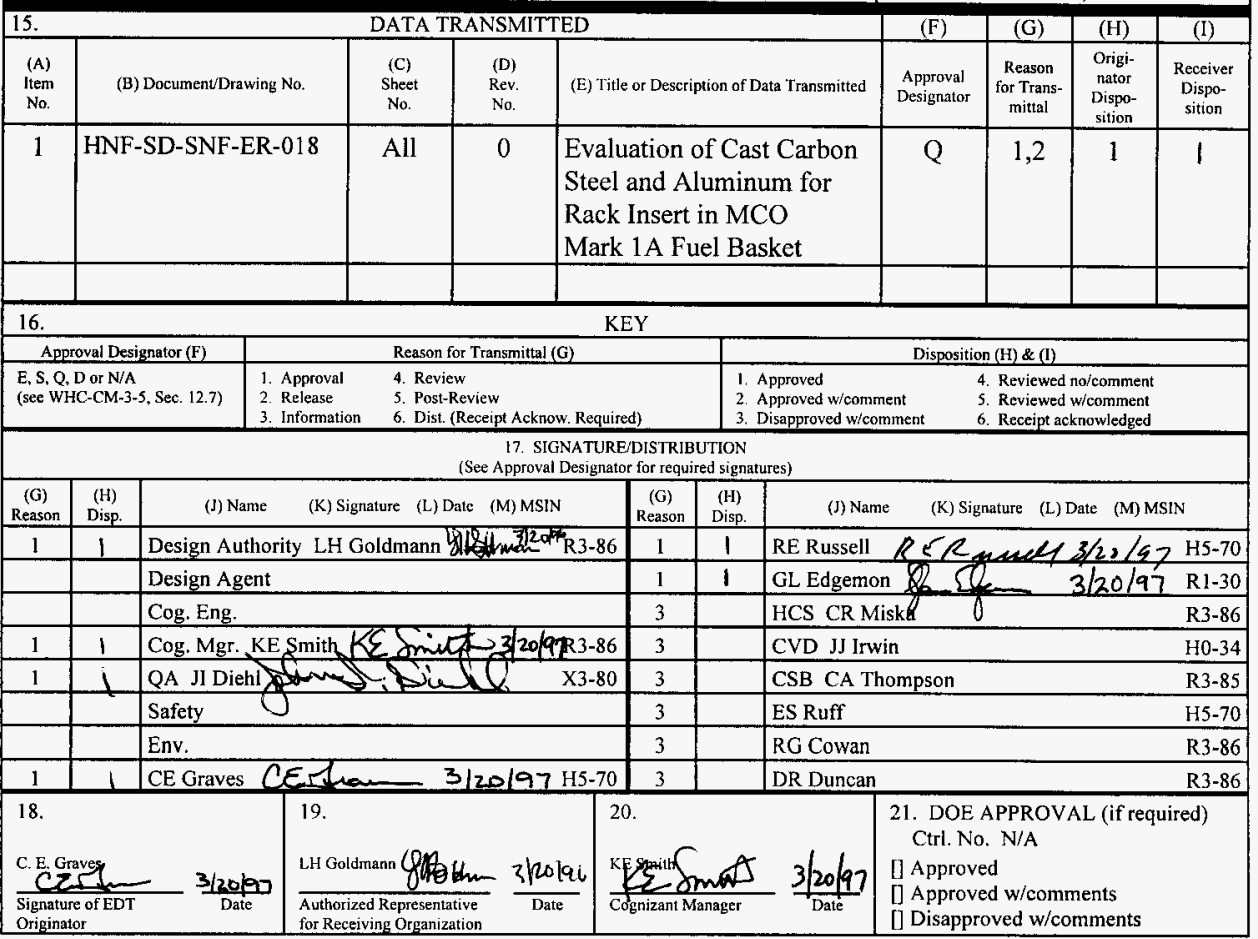




\title{
Evaluation of Cast Carbon Steel and Aluminum for Rack Insert in MCO Mark 1A Fuel Basket
}

\author{
Carolyn E. Graves \\ Fluor Daniel Northwest, Richland, WA 99352 \\ U.S. Department of Energy Contract DE-AC06-96RL-13200
}

EDT/ECN: 604532

UC: 504

Org Code: 481

Charge Code: LE008

B\&R Code: EW7040000

Total Pages: 27

Key Words: MCO

Mark 1A

Spent Nuclear Fuel

Carbon Steel

Aluminum

Fuel Basket

Abstract:

This document evaluates the effects of using a cast carbon steel or aluminum instead of 304L stainless steel in the construction of the fuel rack insert for the Spent Nuclear Fuel MCO Mark $1 \mathrm{~A}$ fuel baskets. The corrosion, structural, and cost effects are examined.

TRADEMARK DISCLAIMER. Reference herein to any specific commercial product, process, or service by trade name, trademark, manufacturer, or otherwise, does not necessarily constitute or imply its endorsement, recommendation, or favoring by the United States Government or any agency thereof or its contractors or subcontractors.

Printed in the United States of America. To obtain copies of this document, contact: Document Control Services, P.O. Box 1970, Mailstop H6-08, Richland WA 99352, Phone (509) 372-2420; Fax (509) 376-4989.
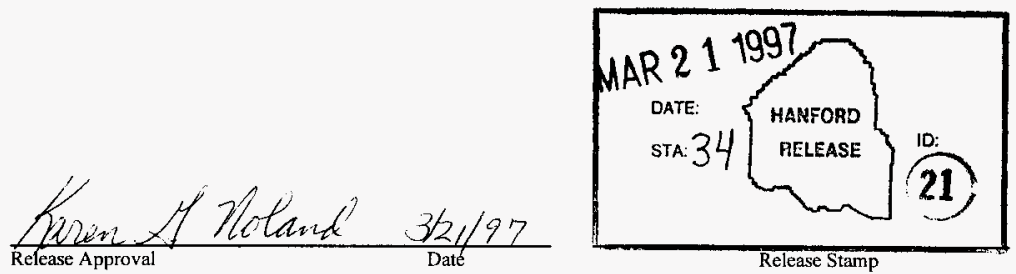

\section{APPROVED FOR PUBLIC RELEASE}


HNF-SD-SNF-ER-018

Revision 0

\title{
EVALUATION OF CAST CARBON STEEL AND ALUMINUM FOR RACK INSERT IN MCO MARK 1A FUEL BASKET
}

\begin{abstract}
The K Basin Spent Nuclear Fuel (SNF) Project Multi-Canister Overpack (MCO) subproject includes the design and fabrication of a canister that will be used to confine, contain, and maintain fuel in a critically safe array to enable its removal from the $K$ Basins. Each MCO consists of a shell, shield plug, fuel baskets (Mark $1 A$ or Mark IV), and other incidental equipment. A fuel rack insert in the Mark $1 A$ intact fuel baskets is not required for criticality control, thus the opportunity exists to reduce expenses by constructing the insert from either a cast carbon steel or aluminum alloy instead of $304 \mathrm{~L}$ stainless steel.

Two alloys were examined for use as alternatives to $304 \mathrm{~L}$ stainless steel in constructing the fuel rack insert for the Mark IA intact fuel baskets: ASTM B26 356.0-T6 sand cast aluminum-silicon alloy, and ASTM A27 Grade 70-36 investment cast carbon steel. The cast carbon steel has mechanical properties similar to $304 \mathrm{~L}$ stainless steel; the cast aluminum has similar room temperature mechanical properties but much lower elevated temperature properties (some of the strength is recovered through radiation embrittlement). The thermal expansion coefficient of aluminum is about double that of the stainless steel and must be taken into consideration during final design. The aluminum alloy exhibits better corrosion resistance in the expected MCO environments than the carbon steel, especially in hydrogen and the galvanic coupling with stainless steel.

Cost quotes for the cast aluminum showed a reduction of material costs by $40 \%$ in comparison to a cast stainless steel similar to wrought $304 \mathrm{~L}$; the cast carbon steel would only reduce material costs by $13 \%$. Therefore, the use of the B26 356.0-T6 aluminum is recommended over the A27 Grade 70-36 carbon steel as the Mark 1 A fuel rack insert construction material.
\end{abstract}


HNF-SD-SNF-ER-018

Revision 0

\section{EVALUATION OF CAST CARBON STEEL AND ALUMINUM FOR RACK INSERT IN MCO MARK 1A FUEL BASKET}

Prepared By:

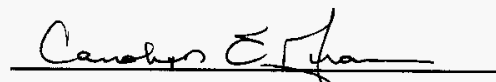

Carolyn E. Graves, Associate Besign Engineer II Mechanisms Engineering

Fluor Daniel Northwest

Reviewed By:

Approved By:

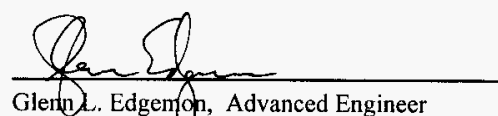

Glenn ג, Edgemon, Advanced Engineer

Materials \& Corrosion Engineering

Lockheed Martin Hanford Corp.
$3 / 20 / 97$

Date

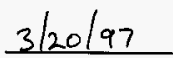

Date
$3 / 20 / 97$

Date

Roy E. Russell Jr., Manager

Mechanisms Engineering

Fluor Daniel Northwest

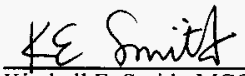

Kimball E. Smith, MCO Subproject Lead

$\frac{3 / 20 / 97}{\text { Date }}$

SNF Storage Projects

Duke Engineering \& Services Hanford

gritustomen

Louis H. Goldmann, MCO Design Authority

SNF Storage Projects

Duke Engineering \& Services Hanford

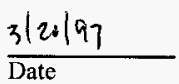




\section{EVALUATION OF CAST CARBON STEEL AND ALUMINUM FOR RACK INSERT IN MCO MARK 1A FUEL BASKET}

TABLE OF CONTENTS

Page

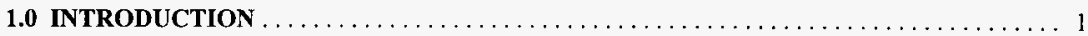

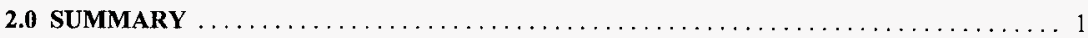

3.0 MARK 1A FUEL BASKET DESCRIPTION $\ldots \ldots \ldots \ldots \ldots \ldots \ldots \ldots \ldots \ldots \ldots$

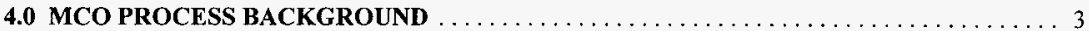

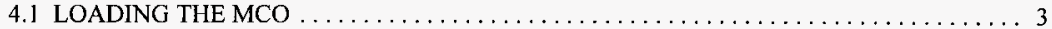

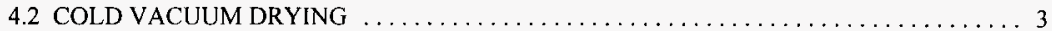

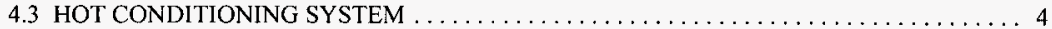

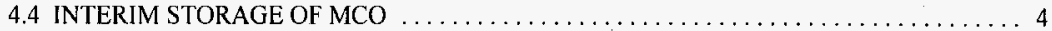

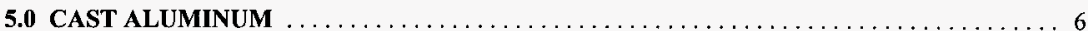

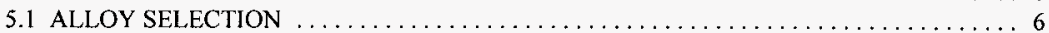

5.2 CORROSION RESISTANCE $\ldots \ldots \ldots \ldots \ldots \ldots \ldots \ldots \ldots \ldots \ldots \ldots \ldots \ldots$

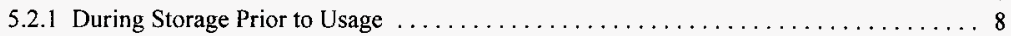

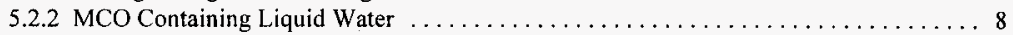

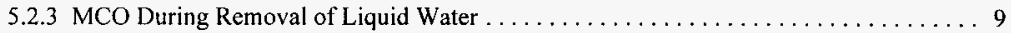

5.2 .4 MCO After Removal of Liquid Water $\ldots \ldots \ldots \ldots \ldots \ldots \ldots \ldots \ldots \ldots \ldots \ldots$

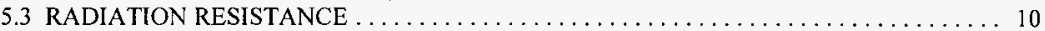

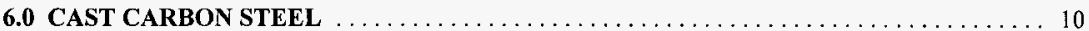

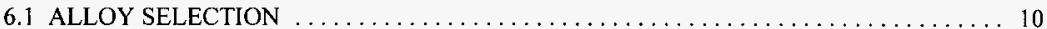

6.2 CORROSION RESISTANCE $\ldots \ldots \ldots \ldots \ldots \ldots \ldots \ldots \ldots \ldots \ldots \ldots \ldots \ldots \ldots \ldots \ldots \ldots$

6.2.1 During Storage Prior to Usage $\ldots \ldots \ldots \ldots \ldots \ldots \ldots \ldots \ldots \ldots \ldots \ldots \ldots \ldots \ldots$

6.2.2 MCO Containing Liquid Water $\ldots \ldots \ldots \ldots \ldots \ldots \ldots \ldots \ldots \ldots \ldots \ldots \ldots \ldots \ldots$

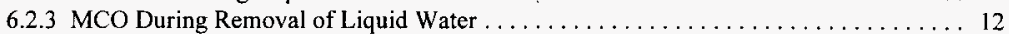

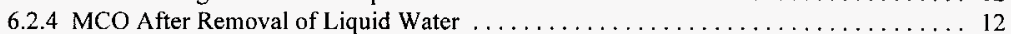

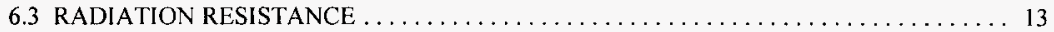

7.0 MCO THERMAL TRANSIENT EFFECTS $\ldots \ldots \ldots \ldots \ldots \ldots \ldots \ldots \ldots \ldots \ldots \ldots$

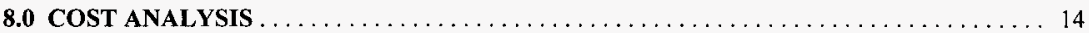

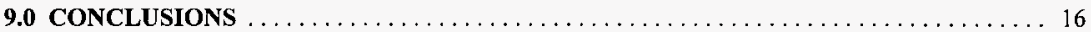

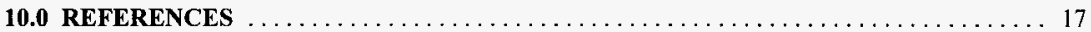

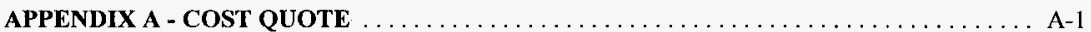




\section{LIST OF TABLES}

Page

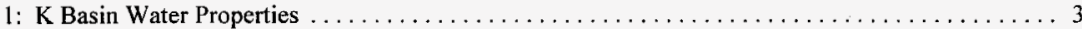

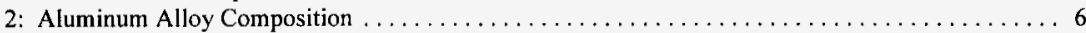

3: Aluminum Alloy Physical Properties $\ldots \ldots \ldots \ldots \ldots \ldots \ldots \ldots \ldots \ldots \ldots \ldots \ldots \ldots \ldots \ldots$

4: Elevated Temperature Tensile Properties of Sand Cast 356.0 T6 $\ldots \ldots \ldots \ldots \ldots \ldots \ldots \ldots 7$

5: Thermal Expansion Coefficients for $356.0 \ldots \ldots \ldots \ldots \ldots \ldots \ldots \ldots \ldots \ldots \ldots \ldots \ldots \ldots$

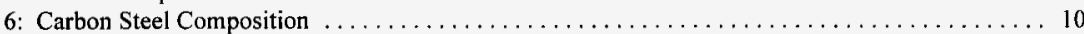

7: Cast Carbon Steel Physical Properties $\ldots \ldots \ldots \ldots \ldots \ldots \ldots \ldots \ldots \ldots \ldots \ldots \ldots \ldots \ldots \ldots \ldots$

8: Cost Quotes for Mark 1A Fuel Rack Insert $\ldots \ldots \ldots \ldots \ldots \ldots \ldots \ldots \ldots \ldots \ldots \ldots \ldots \ldots$

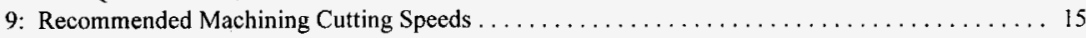

\section{LIST OF FIGURES}

1: MCO Hot Conditioning Temperature Cycle $\ldots \ldots \ldots \ldots \ldots \ldots \ldots \ldots \ldots \ldots \ldots \ldots$ 


\section{ABBREVIATIONS AND ACRONYMS}

\begin{tabular}{|c|c|}
\hline AISI & American Iron and Steel Institute \\
\hline Al & Aluminum \\
\hline ASME & American Society of Mechanical Engineers \\
\hline ASTM & American Society for Testing \& Materials \\
\hline B\&PV & Boiler and Pressure Vessel (Code) \\
\hline C & Carbon \\
\hline $\mathrm{Cr}$ & Chromium \\
\hline $\mathrm{CS}$ & Carbon stee! \\
\hline CSB & Canister Storage Building \\
\hline $\mathrm{Cu}$ & Copper \\
\hline CVD & Cold Vacuum Drying \\
\hline $\mathrm{Fe}$ & Iron \\
\hline FRS & Fuel Retrieval System \\
\hline $\mathrm{HCS}$ & Hot Conditioning System \\
\hline HCSE & Hot Condition System Equipment \\
\hline IXM & Ion Exchange Module \\
\hline KE & $\mathrm{K}$ East Basin \\
\hline ksi & kilopound $/ \mathrm{in}^{2}=1000 \mathrm{psi}\left(\mathrm{l} \mathrm{b} / \mathrm{in}^{2}\right)$ \\
\hline KW & K West Basin \\
\hline $\mathrm{MCO}$ & Multi-Canister Overpack \\
\hline $\mathrm{Mg}$ & Magnesium \\
\hline mil & 0.001 in. \\
\hline Mn & Manganese \\
\hline Mo & Molybdenum \\
\hline $\mathrm{Ni}$ & Nickel \\
\hline OD & Outside diameter \\
\hline $\mathrm{P}$ & Phosphorus \\
\hline PCB & Polychlorinated bipheny! \\
\hline $\mathbf{S}$ & Sulfur \\
\hline $\mathrm{SCC}$ & Stress corrosion cracking \\
\hline $\mathrm{Si}$ & Silicon \\
\hline Sn & Tin \\
\hline SNF & Spent Nuclear Fuel \\
\hline SS & Stainless steel \\
\hline $\mathrm{Ti}$ & Titanium \\
\hline $\mathrm{Zn}$ & Zinc \\
\hline
\end{tabular}




\section{EVALUATION OF CAST CARBON STEEL AND ALUMINUM FOR RACK INSERT IN MCO MARK 1A FUEL BASKET}

\subsection{INTRODUCTION}

The K Basin Spent Nuclear Fuel (SNF) Project Multi-Canister Overpack (MCO) subproject includes the design and fabrication of a canister that will be used to confine, contain, and maintain fuel in a critically safe array to enable its removal from the $\mathrm{K}$ Basins, vacuum drying, transport, staging, hot conditioning, and interim storage (Goldmann 1996). Each MCO consists of a shell, shield plug, fuel baskets (Mark IA or Mark IV), and other incidental equipment.

The Mark 1A fuel baskets are a safety class item for criticality control and will be constructed from 304L stainless steel. Current fuel basket design (for intact fuel elements) includes a fuel rack insert used to maintain the fuel rods in a vertical position. This insert is not required for criticality control, thus the opportunity exists to construct the insert from either a cast carbon steel or aluminum alloy and reduce construction expenses. This report examines the cost, structural, and corrosion effects of using either a cast carbon steel or aluminum instead of stainless steel.

\subsection{SUMMARY}

Two alloys were examined for use as alternatives to 304L stainless steel in constructing the fuel rack insert for the Mark IA intact fuel baskets:

- ASTM B26 356.0-T6 sand cast aluminum-silicon alloy, and

- ASTM A27 Grade 70-36 cast carbon steel (a C-Mn-Si steel similar to wrought AISI 1020)

The cast carbon steel has mechanical properties similar to the $304 \mathrm{~L}$ stainless steel at the design temperatures and pressures (including thermal expansion coefficients). The cast aluminum has similar room temperature mechanical properties as the $304 \mathrm{~L}$ stainless steel. However, elevated temperature strength properties are much lower, about one-third that of the stainless steel. The thermal expansion coefficient of aluminum is about double that of the stainless steel and must be taken into consideration during final design. The aluminum alloy exhibits better corrosion resistance in the expected MCO environments than the carbon steel, especially in the galvanic couple with stainless steel.

Based on cost quotes, the use of the cast aluminum alloy is recommended over the cast carbon steel. The use of carbon steel would result in a 13\% reduction in material costs per 1000 fuel rack inserts; aluminum usage increases this reduction to $40 \%$. The total estimated cost savings in substituting cast carbon steel for the construction of 1000 inserts is $\$ 75 \mathrm{~K}$. The use of cast aluminum would boost this total cost savings to $\$ 226 \mathrm{~K}$. Lower machining costs for aluminum, compared to both the cast carbon and stainless steels, would increase cost savings. 


\subsection{MARK 1A FUEL BASKET DESCRIPTION}

The MCO assembly is a single purpose SNF container that is capable of maintaining SNF subcritical at all times and maintaining SNF containment after having been closed and sealed (Goldmann 1996). The MCO is designed for a 40 year lifetime (extendable to 75 years) with a design pressure of $1.0 \mathrm{MPa}(150 \mathrm{psig})$ and a maximum temperature of $375^{\circ} \mathrm{C}\left(707^{\circ} \mathrm{F}\right)$. The $\mathrm{MCO}$ assembly consists of three parts: shell, shield plug and Mark 1A or Mark IV fuel baskets. With the exception of the Mark IV fuel baskets, the MCO must meet the intent of the American Society of Mechanical Engineers (ASME) Boiler and Pressure Vessel (B\&PV) Code, Section III, Subsection NB (ASME 1995) with few exceptions.

The Mark 1A intact fuel baskets, drawing H-2-828060 (DESH 1997), are annular open-top containers of $304 \mathrm{~L}$ stainless stee ${ }^{\ddagger}$ with a maximum outside diameter (OD) of $57.5 \mathrm{~cm}(22.625 \mathrm{in})$. The baskets are of a perforated cylindrical plate design attached to a center post assembly with a sheet metal shroud about the plate outer diameter. The baskets are designed to be stackable (in any order) inside the MCO shell with the basket centerline coinciding with the MCO centerline. Each Mark 1A MCO will consist of five intact fuel baskets and one scrap fuel basket (of a slightly different design). Some construction changes are expected as the fuel basket design is still in evolution.

The center post assembly forms the criticality exclusion void and has a $16.83 \mathrm{~cm}(6.625 \mathrm{in}) \mathrm{OD}$. The assembly provides both axial and lateral support for the baskets; it is nested to each basket as well as to the shield plug and the shell bottom. The assembly also accommodates the miscellaneous process tubing.

The basket bottom plate is $2.86 \mathrm{~cm}(1.125$ in) thick with equally spaced $0.64 \mathrm{~cm}(0.25 \mathrm{in})$ diameter holes. The perforations support gas flows needed to properly dry and condition the fuel during processing. For additional structural stability there are six trapezoidal bars located around the basket outer diameter.

The fuel rack insert, part number 16 on drawing $\mathrm{H}-2-828060$, is needed to maintain the fuel elements in a vertical configuration for maximum drying (once hot conditioning is complete, the insert is no longer required). The insert sits atop the perforated bottom plate, separated by an expanded metal spacer $^{t \dagger}$. The insert is $6.35 \mathrm{~cm}(2.5 \mathrm{in})$ thick with an OD of $57.1 \mathrm{~cm}(22.48 \mathrm{in})$ and cutouts to fit around the trapezoid support bars. There are a total of 48 countersunk fuel element holes, each $6.55 \mathrm{~cm}$ ( 2.58 in) in diameter. As the fuel rack is not required for criticality control, it has been given an exception from being an ASME-qualified material. However, the construction material must still be qualified by an American Society for Testing \& Materials (ASTM) specification. Approximately 200 Mark 1A MCOs are required; with five intact fuel baskets per $\mathrm{MCO}$, this translates into a total of 1000 fuel rack inserts.

$¥ 304 \mathrm{~L}$ stainless steel (extra-low-carbon 304 ) was the chosen construction material because it is resistant to carbide precipitation during normal welding temperatures that can lead to weld sensitization (and contribute to stress corrosion cracking) (ASM 1985, pg 30-33).

¥t This spacer is currently specified as Ryerson style "3/3/4 No. 0.081 Hvy." (constructed of aluminum alloy $5005-\mathrm{H} 34)$. 


\subsection{MCO PROCESS BACKGROUND}

The Integrated Process Strategy For Spent Nuclear Fuel Project Facilities recommended the following path forward for the removal of materials from the $\mathrm{K}$ basin:

- desludge and clean the SNF;

- repackage the cleaned SNF into fuel baskets;

- load the fuel baskets into MCOs;

- cold vacuum dry (CVD) the loaded MCOs at the K Basins;

- transport the loaded MCOs to the CSB;

- hot condition (additional drying and passivation) at a CSB annex facility; and

- transfer loaded MCOs into storage tubes at the CSB for interim dry storage while awaiting final disposition.

Fuel movement is currently scheduled to start May 12, 1998 and continue for two years. The total number of MCOs to be processed is approximately 200 from K East (KE) basin and 200 from $\mathrm{K}$ West (KW) basin (O'Neill 1996B). The following sections are reprinted from a companion report on MCO fuel basket material selection (Graves 1997). Process descriptions and steps presented below are approximate and may change as each step's design is completed.

\subsection{LOADING THE MCO}

Once cleaned, the $\mathrm{K}$ basin SNF is loaded underwater into the fuel baskets by the fuel retrieval system (FRS). The properties of the K Basin water are shown in Table 1. While still submerged, the loaded fuel baskets are then inserted into the MCO shell. The MCO is temporarily sealed with some water removed prior to shipment (fuel remains flooded) of the $\mathrm{MCO} /$ cask assembly to the cold vacuum drying facility.

Table 1: K Basin Water Properties (Goldmann 1996)

\begin{tabular}{||l|lr||}
\hline \hline Temperature & 6 to $38^{\circ} \mathrm{C}\left(43\right.$ to $\left.100^{\circ} \mathrm{F}\right)$ \\
\hline$p H$ & 5.5 to 7.5 (Current range) \\
\hline Conductivity & $\mathrm{KE}: \leq 5 \mu \mathrm{S} / \mathrm{cm}$ & $\mathrm{KW}: \leq 2 \mu \mathrm{S} / \mathrm{cm}$ \\
\hline Mineral Content & Chloride: $<1 \mathrm{ppm}$ & Nitrate: $<1 \mathrm{ppm}$ \\
& Sulfate: $<1 \mathrm{ppm}$ & Phosphate: $<1 \mathrm{ppm}$ \\
& Fluoride: $0.25 \mathrm{ppm}$ & Sodium: $1 \mathrm{ppm}$ \\
& Calcium: $2 \mathrm{ppm}$ & Iron: $1 \mathrm{ppm}$ \\
\hline
\end{tabular}

\subsection{COLD VACUUM DRYING}

Cold vacuum drying (CVD) drains the bulk water and vacuum dries the SNF inside the MCO prior to transportation from the K basin to the CSB (O'Neill 1996B). Prior to drying, bulk water is drained from the $\mathrm{MCO}$ via a long axial dip tube while the $\mathrm{MCO}$ temperature is held below $50^{\circ} \mathrm{C}\left(122{ }^{\circ} \mathrm{F}\right)$. A gas purge using either air, helium, nitrogen or argon aids in draining the bulk water. 
Drying of the SNF is performed by heating the MCO to $60^{\circ} \mathrm{C}\left(142^{\circ} \mathrm{F}\right)$ for 48 hours. A vacuum pumping system removes any gases from the MCO during drying (i.e., offgassing, residual free water, inleakage, etc.).

Following fuel drying, the MCO is backfilled with $99.95 \%$ purity helium to $400 \mathrm{~Pa}(0.06$ psi) and temporarily sealed. The $\mathrm{MCO}$ is then heated to $75^{\circ} \mathrm{C}\left(167^{\circ} \mathrm{F}\right)$ for 12 hours to monitor for any pressure buildup (shipping simulation temperature). Following monitoring, the MCO is cooled to $25^{\circ} \mathrm{C}\left(77^{\circ} \mathrm{F}\right.$ ) and prepared for shipment to the CSB to await hot conditioning.

\subsection{HOT CONDITIONING SYSTEM}

The Hot Conditioning System (HCS) removes chemically bound water from the SNF and will also possibly passivate the exposed uranium metal surfaces on the SNF (O'Neill 1996A). This process also minimizes the potential for subsequent pressurization of the sealed MCO by removing constituents that can change phase to a gaseous state under storage conditions (Garvin 1997). The HCS is performed by the hot condition system equipment (HCSE) which will be located in an annex of the CSB.

The hot conditioning cycle takes approximately six days to complete; temperature levels for the different stages of the cycle are shown in Figure 1. Gas purging of the MCO is performed in conjunction with the heating to remove unwanted gases (chemically bound water, fission gases, air, etc.) and to maintain the hydrogen concentration below 2 volume percent. During the backfill stage, the MCO is filled with $99.95 \%$ purity helium to a gauge pressure of $21-50 \mathrm{kPa}(3-7.3 \mathrm{psi})$ and sealed for storage. Once conditioned, the $\mathrm{MCO}$ is not expected to need venting during interim dry storage at the CSB (Garvin 1997). However, a pressure relief device will be active at all times in the unexpected event of MCO overpressurization.

\subsection{INTERIM STORAGE OF MCO}

After sealing, the $\mathrm{MCO} /$ cask assembly returns to the CSB for dry interim storage until a suitable long-term repository can be established. Expected storage temperatures at the CSB are -10 to $132{ }^{\circ} \mathrm{C}$ (14 to $270^{\circ} \mathrm{F}$ ). 
Figure 1: MCO Hot Conditioning Temperature Cycle (O’Neill 1996A)

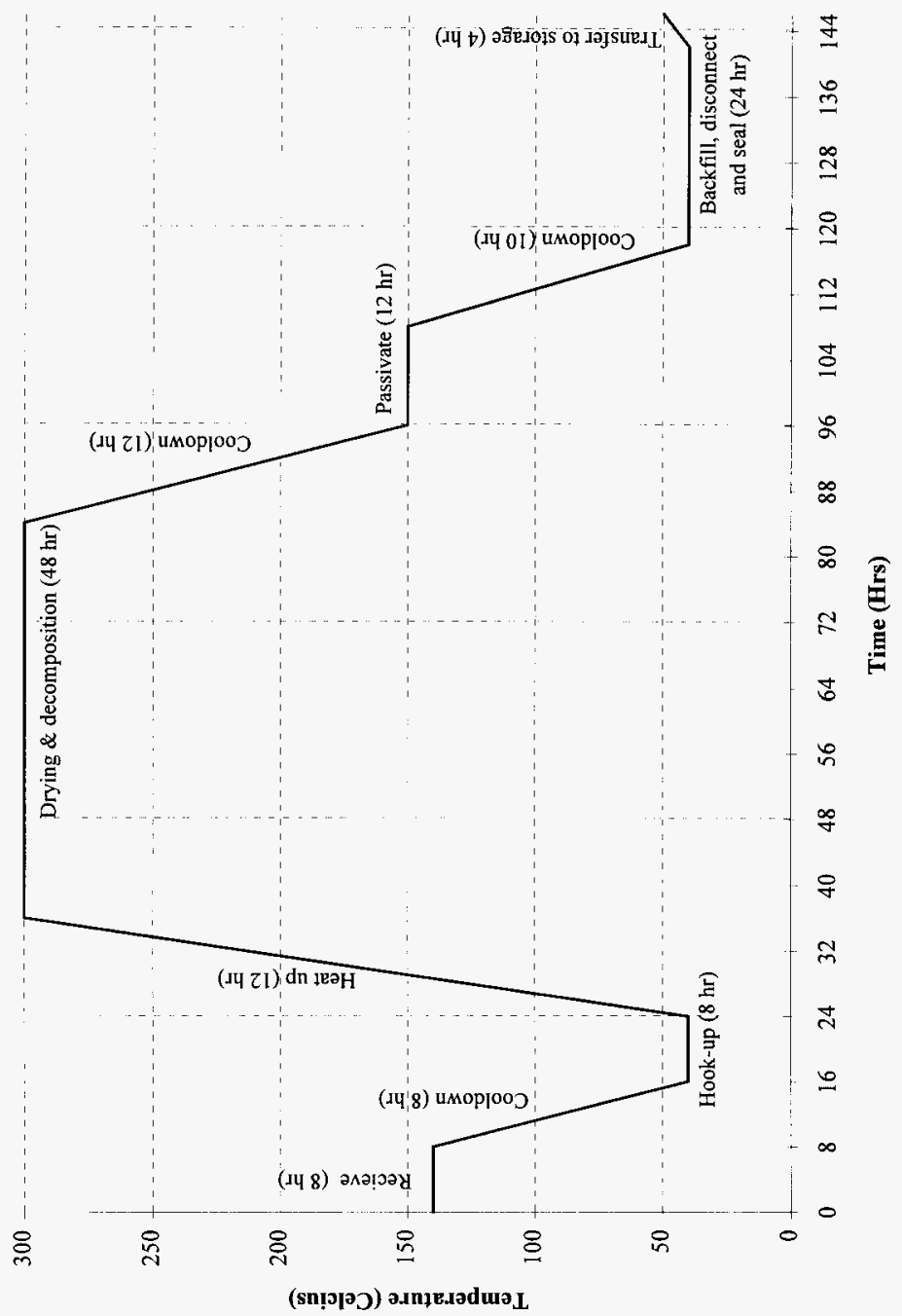




\subsection{CAST ALUMINUM}

Aluminum casting alloys are based on the same alloy systems as wrought alloys. There are six families of cast aluminum alloys ( $1 X X$ is the designation for unalloyed aluminum):

- $2 X X: \mathrm{A} 1-\mathrm{Cu}$ alloys capable of the highest strengths (including at elevated temperatures) but sacrifice corrosion resistance.

- $3 X X: \mathrm{Al}-\mathrm{Si}$ alloys with $\mathrm{Mg}$ and/or $\mathrm{Cu}$ exhibit excellent casting characteristics, weldability, and corrosion resistance. These alloys have the highest volume usage in the cast aluminum industry.

- $4 X X: \mathrm{Al}-\mathrm{Si}$ alloys have superior casting characteristics, moderate strengths, and high corrosion resistance, ductility and impact resistance.

- $5 X X: \mathrm{Al}-\mathrm{Mg}$ alloys characterized by excellent corrosion resistance and good machinability.

- $7 X X:$ Al-Zn alloys display high melting points and good finish characteristics, corrosion resistance, and machinability.

- $8 X X:$ Al-Sn alloys that were developed as bearing materials with high load-carrying capacity and fatigue strength.

Almost all alloys within the $2 \mathrm{XX}, 5 \mathrm{XX}, 7 \mathrm{XX}$, and $8 \mathrm{XX}$ systems have limited casting configurations; greater care in mold design is required to produce highest-quality castings (ASM 1985, pg 6.51). Most alloys require some type of heat treatment following casting in order to obtain desired strength levels.

\subsection{ALLOY SELECTION}

Based upon their excellent casting and corrosion resistance properties, a $3 \mathrm{XX}$ alloy was chosen for the fuel rack insert. A $2 \mathrm{XX}$ alloy would have provided higher strength levels during hot conditioning, however, its much poorer corrosion resistance was deemed unacceptable. The 356.0 alloy was chosen as it is a standard general purpose alloy with excellent casting and corrosion characteristics (see Table 2 for chemical composition). Its typical uses include automotive transmission cases, and aircraft fittings/structures (Kearney 1990B). A T6 temper, solution heat treated and artificially aged, achieves the alloy's higher strength properties. With the relatively small number of inserts required, it was concluded that sand casts would be cheaper and more timely to produce than permanent mold casts. The tensile properties of ASTM B26 sand cast 356.0-T6, as listed by the standard (ASTM 1996), are shown in Table 3.

Table 2: Aluminum Alloy Composition (ASTM 1996)

\begin{tabular}{||c|c|c|c|c|c|c|c|c||}
\hline \multirow{2}{*}{ Material } & \multicolumn{7}{|c||}{ Composition in weight percent (Remainder is Aluminum) } \\
\cline { 2 - 9 } & $\mathbf{S i}$ & $\mathbf{F e}$ & $\mathbf{C u}$ & $\mathbf{M n}$ & $\mathbf{M g}$ & $\mathbf{N i}$ & $\mathbf{Z n}$ & $\mathbf{T i}$ \\
\hline ASTM B26 356.0 & $6.5-7.5$ & 0.6 & 0.25 & 0.35 & $0.2-0.45$ & -- & 0.35 & 0.25 \\
\hline
\end{tabular}

Table 3: Aluminum Alloy Physical Properties (ASTM 1996)

\begin{tabular}{|c|c|c|c|c|}
\hline Material & Temper & $\begin{array}{c}\text { Tensile Strength, min. } \\
\text { MPa (ksi) }\end{array}$ & $\begin{array}{c}\text { Yield Strength*, min. } \\
\text { MPa (ksi) }\end{array}$ & $\begin{array}{c}\text { Elongation in 2 in., } \\
\text { min. \% }\end{array}$ \\
\hline ASTM B26 356.0 & T6 & $207(30.0)$ & $138(20.0)$ & 3.0 \\
\hline
\end{tabular}


Typical elevated temperature tensile properties for sand cast 356.0-T6 are listed in Table 4. Note that at the hot conditioning temperature, $300^{\circ} \mathrm{C}\left(570^{\circ} \mathrm{F}\right)$, the yield strength of the alloy is only about $15 \%$ of its room temperature value; only about $33 \%$ that of stainless steel (ASME 1995). Even with this reduced strength, the fuel rack insert should be able to maintain the fuel elements in their vertical configuration during hot conditioning (the $\mathrm{MCO}$ is stationary and not moved until it cools down to $132{ }^{\circ} \mathrm{C}\left[270^{\circ} \mathrm{F}\right]$ ) . A simple stress analysis should be done to ensure that the aluminum insert web has enough strength to keep a 'leaning' fuel element upright during hot conditioning.

Table 4: Elevated Temperature Tensile Properties of Sand Cast 356.0 T6 (Kearney 1990B)

\begin{tabular}{|c|c|c|c|c|c|c||}
\hline \hline \multicolumn{2}{|c|}{ Test Temperature } & \multicolumn{2}{c|}{ Tensile Strength } & \multicolumn{2}{c|}{ Yield Strength } & \multirow{2}{*}{$\begin{array}{c}\text { Elongation in } \\
\text { 50 mm (2 in) }\end{array}$} \\
\hline${ }^{\circ} \mathbf{C}$ & ${ }^{\circ} \mathbf{F}$ & $\mathbf{M P a}$ & $\mathbf{k s i}$ & $\mathbf{M P a}$ & $\mathbf{k s i}$ & 3.5 \\
\hline 24 & 75 & 228 & 33 & 165 & 24 & 4.0 \\
\hline 100 & 212 & 221 & 32 & 165 & 24 & 6.0 \\
\hline 150 & 300 & 159 & 23 & 138 & 20 & 18.0 \\
\hline 205 & 400 & 83 & 12 & 59 & 8.5 & 35.0 \\
\hline 260 & 500 & 52 & 7.5 & 34 & 5 & 60.0 \\
\hline 315 & 600 & 28 & 4 & 21 & 3 & 80.0 \\
\hline 370 & 700 & 17 & 2.5 & 14 & 2 & \\
\hline
\end{tabular}

The thermal expansion coefficients for a 356.0 cast aluminum are shown in Table 5 . In comparison with stainless steel, the aluminum values are approximately double. This amount of thermal expansion could affect the required design tolerances and must be taken into consideration during final design. The performance of a thermal expansion analysis is recommended to ensure that the aluminum insert doesn't enlarge and crack the welds of the fuel basket sidewall when exposed to hot conditioning temperatures.

Table 5: Thermal Expansion Coefficients for 356.0 (Kearney 1990B)

\begin{tabular}{||c|c|c|c||}
\hline \multicolumn{2}{|c|}{ Temperature Range } & \multicolumn{2}{c|}{ Average Coefficient } \\
\hline${ }^{\circ} \mathrm{C}$ & ${ }^{\circ} \mathrm{F}$ & $\times 10^{-6}\left({ }^{\circ} \mathrm{C}\right)^{-1}$ & $\times 10^{-6}\left({ }^{\circ} \mathrm{F}\right)^{-1}$ \\
\hline $20-100$ & $68-212$ & 21.5 & 11.9 \\
\hline $20-200$ & $68-392$ & 22.5 & 12.5 \\
\hline $20-300$ & $68-572$ & 23.5 & 13.1 \\
\hline
\end{tabular}




\subsection{CORROSION RESISTANCE}

Aluminum owes its excellent corrosion resistance to the barrier oxide film that is bonded strongly to its surface and that, if damaged, re-forms immediately in most environments (Hollingsworth et al 1987). Under most environmental conditions frequently encountered in service, aluminum and its alloys are the anodes in galvanic cells with most other metals, protecting them by corroding sacrificially. The microstructures of casting alloys are nearly isotropic; consequently, resistance to stress corrosion cracking (SCC) is unaffected by orientation of tensile stresses (Hollingsworth et al 1987). The $3 X X$ alloys containing only silicon and magnesium as alloying additions have virtually no susceptibility to $\mathrm{SCC}$. The $3 \mathrm{XX}$ alloys containing appreciable amounts of copper are less resistant.

\subsubsection{During Storage Prior to Usage}

The MCO components will need to be stored prior to actual fuel loading, most likely in a combination of dry (warehouse) and wet (basin) conditions. Atmospheric corrosion (weathering) of aluminum is restricted to mild surface roughening by shallow pitting, with no general thinning (Hollingsworth et al 1987). The aluminum corrosion rate decreases with time to a relatively low, steady state rate; in rural atmospheres it may be less than $0.025 \mu \mathrm{m} / \mathrm{yr}(0.001 \mathrm{mils} / \mathrm{yr}$ ) (ASM 1985, pg 6.65).

Aluminum is highly resistant to high-purity water (distilled or demineralized) at ambient temperatures. The slight reaction with the water that occurs initially ceases almost completely within a few days after development of a protective oxide film. After this conditioning period, the amount of metal dissolved by the water becomes negligible (Hollingsworth et al 1987). Measured corrosion rates in the KE basin for either a 5086 or 6061 wrought aluminum are less than $0.5 \mu \mathrm{m} / \mathrm{yr}(0.02 \mathrm{mils} / \mathrm{yr})$; similar corrosion rates are expected for the cast aluminum alloy.

\subsubsection{MCO Containing Liquid Water}

The resistance of aluminum alloys to water is discussed in the previous section.

The main dissimilar metal contact scenario within the MCO is contact between the aluminum fuel rack insert and the stainless steel baskets. In many environments, including freshwater, aluminum can be used in contact with stainless steels with only a slight acceleration of corrosion; stainless steels are easily polarized cathodically in mild environments, so that the corrosion current is small (Hollingsworth et al 1987). However, the fuel rack insert is the only non-304L component within the MCO (besides the expanded metal spacer), thus, the area ratio of stainless steel to aluminum is very large. Even with an assumed 1000 -fold corrosion rate increase, accelerated corrosion of the aluminum would only be $0.5 \mathrm{~mm} / \mathrm{yr}(20 \mathrm{mils} / \mathrm{yr})$.

There are two other possible dissimilar metal contact scenarios within the MCO which could result in accelerated galvanic corrosion of the aluminum insert:

1) Contact with Zircaloy-2 fuel cladding - The zirconium-based cladding forms a passive oxide film that is much more noble in seawater in comparison to aluminum. Thus, accelerated galvanic corrosion of the aluminum is expected.

2) Contact with uranium fuel - A previous galvanic couple test (Weirick 1987) of uranium (U-581) with aluminum in $100 \%$ relative humidity showed only a slight corrosive attack for both the aluminum and the uranium. 
The time period during which an MCO is immersed in or is filled with liquid water is less than 2 days (Garvin 1997). Even with accelerated galvanic corrosion effects, this is an insufficient time period for significant corrosion of the aluminum fuel rack inserts to occur. Should a problem occur during processing causing a backlog, storage of a flooded MCO should be limited to less than 6 months.

\subsubsection{MCO During Removal of Liquid Water}

Less than 48 hours is needed to remove liquid water from the MCO and establish a low water vapor pressure inside (WHC 1996). As with the stainless steel, this period is too short to cause significant corrosion of the aluminum as there is no significant build up of aggressive species. The low water vapor pressure, less than $66 \mathrm{~Pa}(0.01 \mathrm{psi})$, following the cold vacuum drying prevents any condensation inside the MCO. Once the liquid water is removed and condensation is precluded, liquid [galvanic] corrosion problems cease (Garvin 1997).

\subsubsection{MCO After Removal of Liquid Water}

Following hot conditioning, there is the potential for four gases to exist within the MCO in addition to inert gases:

1) Hydrogen gas - Generated by reactions of the uranium fuel with water vapor or radiolysis of chemically bound water.

2) Chlorine gas - Produced by thermal or radiolytic decomposition of PCBs (detected in sludge samples). However, PCBs are not expected in the $\mathrm{K}$ basin canister sludge, so it should not be present within the $\mathrm{MCO}$.

3) Iodine gas - Could be present due to the thermal environment and fuel corrosion.

4) Oxygen gas - Generated by the radiolysis of water.

Aluminum is considered to be resistant to hydrogen at temperatures approaching its melting point of $660^{\circ} \mathrm{C}\left(1220^{\circ} \mathrm{F}\right)$ (Berry 1971). Dry hydrogen gas is not detrimental to aluminum alloys; however, with the addition of water vapor, subcritical crack growth increases dramatically. It is more common to form a multitude of near-surface voids that coalesce to produce a large blister (Craig 1987).

In chlorine gas, aluminum is usable up to $120^{\circ} \mathrm{C}\left(250^{\circ} \mathrm{F}\right)$ and moisture at room temperature increases attack. At higher temperatures, above $130^{\circ} \mathrm{C}\left(265^{\circ} \mathrm{F}\right)$, moisture decreased attack (Liening 1987). As PCBs are not expected within the $\mathrm{MCO}$ and regular gas purging occurs during processing, chlorine gas corrosion problems are not expected.

A literature search did not yield any recommendations concerning aluminum service in iodine gas. Since iodine is less aggressive than chlorine (assuming an equivalent partial pressure) and iodine levels are low, corrosion attack of aluminum from iodine is unlikely.

Oxygen gas has no effect on aluminum (it aids in the formation of a protective oxide coating) (Chawla et al 1993).

In addition to gaseous corrosion reactions, contact between the fuel rack insert and the fuel elements could cause liquid metal embrittlement by fuel fission products. Cesium and tin are the low melting point fission products, less than $205^{\circ} \mathrm{C}\left(400^{\circ} \mathrm{F}\right)$, generated in the greatest amounts (Garvin 1997). Aluminum alloys are embrittled by tin-zinc and lead-tin alloys (susceptibility related to heat treatment and the strength level of the alloy). The alkali metals sodium and lithium, sister elements to cesium, are known to embrittle aluminum (Kamdar 1987). However, as the tin and cesium levels in the fuel elements are low, content in a contact area would be far too small for significant damage to occur. 


\subsection{RADIATION RESISTANCE}

The less strong aluminum alloys can be appreciably strengthened by irradiation with only small reductions in elongation (Berggren 1965). A contact dose rate for the MCO without the shield plug or cask was calculated to be less than $600 \mathrm{rem} / \mathrm{hr}$ for an approximate average of all Mark $1 \mathrm{~A}$ and Mark IV fuel (Lan et al 1996). This dose rate was based on photon calculation as the neutron source strength is much less than the photon source strength. Neutron irradiation ${ }^{\ddagger}$ at $50^{\circ} \mathrm{C}\left(120^{\circ} \mathrm{F}\right)$ of alloy A356.0-T6 (lower iron content than 356.0 ) demonstrated a $200 \%$ increase in yield strength with only a $25 \%$ decrease in elongation (Kearney 1990B). This strength increase would aid in insert stability during the hot conditioning processing temperatures.

\subsection{CAST CARBON STEEL}

Cast carbon steels are separated into three categories based on carbon content: low $(<0.20 \%)$, medium $(0.20 \%<\mathrm{C}<0.50 \%)$, and high $(>0.50 \%)$. The medium-carbon cast grades represent the bulk of cast steel production. A comparison between a cast carbon steel and a wrought carbon steel of the same composition show similar mechanical and physical properties, including: response to heat treatment, weldability, machinability, and corrosion resistance (Blair 1990).

\subsection{ALLOY SELECTION}

An ASTM A27 Grade 70-36 cast carbon steel (ASTM 1995B) was chosen as an alternative material for the fuel rack insert. This is a medium-carbon cast steel that was also used for casting the Mark IV base plate during the MCO prototype development (see Table 6 for approximate chemical composition). Chemistry control tests by the casting company (Midwest Precision Casting Co. of O'Fallon, Missouri) decided on a carbon content of $0.20 \%$ for the desired mechanical properties. This essentially places the cast alloy in the low-carbon cast steel category; this benefits in finish machining costs and labor as low-carbon steels have faster cutting speeds.

Table 6: Carbon Steel Composition (ASTM 1995B)

\begin{tabular}{|c|c|c|c|c|c|}
\hline \multirow{2}{*}{ Material } & \multicolumn{5}{|c|}{ Composition in weight \% (Remainder is Iron) } \\
\cline { 2 - 6 } & $\mathbf{C}, \max$ & $\mathbf{M n}, \max$ & $\mathbf{S i}, \max$ & $\mathbf{S}, \max$ & $\mathbf{P}, \max$ \\
\hline ASTM A27 Grade 70-36 & 0.35 & 0.70 & 0.80 & 0.06 & 0.05 \\
\hline
\end{tabular}

Tensile properties for the cast carbon steel (per the ASTM specification) are listed in Table 7. Elevated temperature tensile data for this particular cast alloy was not found in a literature search, however, it would be comparable to that of the ASTM A516, grade 70 wrought carbon steel (and the stainless steel) discussed in the companion MCO material selection report (Graves 1997).

\footnotetext{
$\ddagger$ Utilizing a fast neutron flux rate of $9.8 \times 10^{20} \mathrm{n} / \mathrm{cm}^{2}$. Slower flux rates yielded proportionally smaller strength increases (elongation actually increased by $50 \%$ ).
} 
Table 7: Cast Carbon Steel Physical Properties (ASTM 1995B)

\begin{tabular}{|c|c|c|c|c|}
\hline Material & $\begin{array}{c}\text { Tensile Strength, } \\
\text { min., MPa (ksi) }\end{array}$ & $\begin{array}{c}\text { Yield Strength*, } \\
\text { min., MPa (ksi) }\end{array}$ & $\begin{array}{c}\text { \% Elongation in } \\
\text { 2 in., min. }\end{array}$ & $\begin{array}{c}\text { \% Reduction of } \\
\text { Area, min. }\end{array}$ \\
\hline ASTM A27 Grade 70-36 & $482(70)$ & $248(36)$ & 22 & 30 \\
\hline
\end{tabular}

\subsection{CORROSION RESISTANCE}

Corrosion resistance of cast steel is similar to that of wrought steel of equivalent composition. Data published on the corrosion resistance of wrought carbon steels under various conditions may be applied to cast steels (Blair 1990). The cast alloy chosen is close in composition and strength properties to the ASTM/ASME A516, grade 70 steel discussed in a companion report (Graves 1997) that evaluates carbon steel for use in constructing the MCO Mark IV fuel baskets. As the corrosion resistance would also be similar, the following sections will summarize the information discussed in the companion report.

\subsubsection{During Storage Prior to Usage}

Storage of the fuel rack inserts will be a combination of dry (warehouse) and wet (basin) conditions. Atmospheric corrosion of carbon steel in an arid rural environment (Phoenix, Arizona), similar to the Hanford Reservation, is $0.005 \mathrm{~mm} / \mathrm{yr}(0.18 \mathrm{mils} / \mathrm{yr}$ ) (ASM 1985, pg 4.90). As condensate or rainwater buildup could cause localized pitting corrosion, low-humidity inside storage is recommended. The corrosion rate in the $\mathrm{KE}$ basin for a 1018 carbon steel is less than $0.05 \mathrm{~mm} / \mathrm{yr}(2 \mathrm{mils} / \mathrm{yr})$ with little to no pitting corrosion observed (Emory 1994). The corrosion rate of the cast carbon steel would be similar. Corrosion impact to the basins during storage (i.e., visibility, basin filters, basin ion exchange modules, etc.) would be negligible in comparison to corrosion from existing piping and structures.

\subsubsection{MCO Containing Liquid Water}

The time period during which an MCO is immersed in or is filled with liquid water is less than 2 days (Garvin 1997). The resistance of carbon steel to the $K$ basin water environment is discussed in the previous section.

The most prominent galvanic reaction is the stainless steel baskets in physical and/or electrical contact with the carbon steel fuel rack insert. Stainless steel is more noble (less likely to corrode) than carbon steel; when in contact, the corrosion rate of the carbon steel will increase while the corrosion rate of the stainless steel remains the same or decreases. In the MCO, the surface area ratio of the stainless steel to the carbon steel is very large ("1); a significant increase in the carbon steel corrosion rate is thus expected. Assuming a 1000-fold enhancement for the galvanically coupled carbon steel corrosion rate (as compared to the uncoupled rate) the corrosion rate would escalate to $50 \mathrm{~mm} / \mathrm{yr}$ ( $2 \mathrm{in} / \mathrm{yr})^{\ddagger}$.

Two other possibilities exist for dissimilar metal contact with the fuel rack inserts within the MCO:

1) Contact with Zircaloy-2 fuel cladding - The zirconium cladding is much more noble in seawater in comparison to carbon steel; accelerated galvanic corrosion of the carbon steel is expected.

2) Contact with uranium fuel - Examination of previous galvanic corrosion studies show uranium alloys to be more noble than the carbon steel (Weirick 1987); accelerated galvanic corrosion of the carbon steel is expected.

\footnotetext{
$\$$ This is a conservative estimate of the galvanic corrosion effect within a water-filled MCO.
} 
This accelerated galvanic corrosion could be detrimental to the functioning ability of the insert, even during the short immersion time. The amounts of corrosion product could also affect processing ability (i.e., by plugging up process piping, filters, etc.).

\subsubsection{MCO During Removal of Liquid Water}

The cold vacuum drying period (48 hours) is too short to cause significant corrosion of the carbon steel as there is no significant build up of aggressive species. The low water vapor pressure prevents any condensation inside the MCO. Once the liquid water is removed and condensation is precluded, liquid corrosion problems cease (Garvin 1997).

Anantatmula and Colburn (1992) observed an increase in the air/steam corrosion of carbon steels at $250^{\circ} \mathrm{C}\left(480^{\circ} \mathrm{F}\right)$ to $0.013 \mathrm{~mm} / \mathrm{yr}(0.5 \mathrm{mil} / \mathrm{yr})$. Radiological testing conditions varied between $1000 \mathrm{R} / \mathrm{hr}$ and $10,000 \mathrm{R} / \mathrm{hr}$. However, if the moisture film galvanically couples the carbon steel to stainless steel, the corrosion rate could be as high as $0.13 \mathrm{~mm} / \mathrm{yr}(5 \mathrm{mil} / \mathrm{yr})^{\ddagger}$. Although this corrosion rate is almost a factor of 3 higher than the aqueous corrosion rate (Emory 1994), it is not a matter of concern since the moisture will be quickly driven away from the MCO.

\subsubsection{MCO After Removal of Liquid Water}

Following the hot conditioning process, there is the potential for four gases to exist within the MCO in addition to inert gases:

1) Hydrogen gas - An AISI 1020 steel hydrogen-charged at room temperature (low strain rate) exhibited a drop in the reduction-of-area from $72 \%$ to $42 \%$ (Vander Voort 1990). Higher temperatures and higher strain rates would both result in much smaller ductility losses. For the MCO's environment and temperatures, neither hydrogen blistering nor hydrogen attack are a concern.

2) Chlorine gas - Carbon steel is regularly used to ship and handle dry chlorine. A dry chlorine maximum-use temperature of $200^{\circ} \mathrm{C}\left(400^{\circ} \mathrm{F}\right)$ is recommended for a clean grease-free steel (Liening 1987). Any moisture will greatly accelerate attack, however, this is unlikely to occur because the water vapor pressure will be very low following hot conditioning. As PCBs are not expected in the $\mathrm{MCO}$ and regular gas purging occurs during hot conditioning, a chlorine corrosion problem is not expected.

3) lodine gas - A corrosion literature search did not yield any recommendations for carbon steel usage in dry iodine. As iodine is less aggressive than chlorine, corrosion attack of carbon steel by iodine gas would be unlikely.

4) Oxygen gas - Carbon steel corrosion resistance to oxygen is similar to its atmospheric corrosion resistance (see section 6.2.1). At higher temperatures corrosion occurs by direct reaction with the gas and oxide scales form (rate of attack increases with temperature). At $480^{\circ} \mathrm{C}\left(900^{\circ} \mathrm{F}\right)$ the metal loss from scaling for carbon steel is $0.1 \mathrm{~mm} / \mathrm{yr}$ (3.9 mils/yr) (ASM 1990). Metal loss rates at hot conditioning temperatures would be slightly less.

$\ddagger$ The corrosion rate increase is smaller due to the greatly reduced conductivity between materials in a moist environment versus that in an immersed environment. 
Contact between the fuel and the fuel rack inserts could cause liquid metal embrittlement of the carbon steel by fission products (cesium and tin). Maximum temperature recommendations for the longterm use of low-alloy steels in liquid sodium and lithium (sister elements to cesium) are $450{ }^{\circ} \mathrm{C}\left(840^{\circ} \mathrm{F}\right.$ ) and $300^{\circ} \mathrm{C}\left(570^{\circ} \mathrm{F}\right)$, respectively (ASM 1990). Low-alloy steels have good resistance to liquid tin only up to $150^{\circ} \mathrm{C}\left(300^{\circ} \mathrm{F}\right.$ ) (ASM 1990). As the tin and cesium levels per fuel element are small, content in a contact area is far too small to cause significant damage.

\subsection{RADIATION RESISTANCE}

Irradiation of ferritic steels can cause increases in the nil-ductility transition (NDT) temperature (transition of brittle to ductile fracture). For the majority of carbon steels, the NDT is below room temperature. A contact dose rate for the MCO without the shield plug or cask was calculated to be less than $600 \mathrm{rem} / \mathrm{hr}$ for an approximate average of all Mark 1A and Mark IV fuel (Lan et al 1996). This dose rate was based on photon calculation as the neutron source strength is much less than the photon source strength. For these conditions, an estimate of the effect of the radiation damage on the NDT of an ASTM A-5 16 carbon steel is an increase of about $3.6^{\circ} \mathrm{C}\left(6.4^{\circ} \mathrm{F}\right)$ (Carlos et al 1994). The cast carbon steel alloy would undergo a similar NDT increase.

\subsection{MCO THERMAL TRANSIENT EFFECTS}

After drying of the $\mathrm{MCO}$ and on initial heat up, the fuel particulates inside the MCO will release water from crystalline forms. This free water vapor will then react with any bare uranium metal or hydrides to produce heat which may result in a thermal transient. The upper temperatures inside the MCO may then momentarily exceed $300^{\circ} \mathrm{C}\left(570^{\circ} \mathrm{F}\right)$. This generated a concern that the thermal transient temperatures could approach the eutectic (solid to liquid) temperature of the fuel rack insert material.

Calculations performed by Thurgood (1997) showed that for the bounding case (staging) the peak fuel temperature was $443^{\circ} \mathrm{C}\left(830^{\circ} \mathrm{F}\right)$ and the peak MCO wall temperature was $261^{\circ} \mathrm{C}\left(500^{\circ} \mathrm{F}\right)^{\ddagger}$. The calculations used the surface area and water inventory of the scrap fuel basket (worst case scenario) and the following assumptions: maximum sludge amount of $54.4 \mathrm{~kg}(120 \mathrm{lb})$, a water mass fraction of the sludge equal to or less than $10 \%$, and individual scrap pieces do not exceed $20 \%$ oxide. Calculations for shipping yielded lower peak temperatures than for staging (calculations for CVD are not yet complete).

Both of these calculated peak temperatures fall well below the documented safety limit temperatures. The maximum MCO operational limit temperature is $375^{\circ} \mathrm{C}\left(700^{\circ} \mathrm{F}\right)$, as documented by Goldmann (1996). The maximum fuel safety limit temperature of $725^{\circ} \mathrm{C}\left(1340^{\circ} \mathrm{F}\right)$ is the uranium-iron eutectic temperature as documented in the MCO Topical Report (Garvin 1997).

The eutectic transformation temperature is $660^{\circ} \mathrm{C}\left(1220^{\circ} \mathrm{F}\right)$, equal to aluminum's melting point, for both the aluminum-uranium and aluminum-zirconium systems (ASM 1992). Aluminum has the lowest melting point and thus is the limiting metal in any reaction product. As the transformation temperature is considerably above the calculated thermal transient, the likelihood of any aluminum eutectic reactions is negligible. This same conclusion is also applicable for iron eutectic reactions.

$\ddagger$ These calculations are expected to be updated in March/April 1997. 


\subsection{COST ANALYSIS}

Cost estimates for the cast stainless steel (baseline) and cast carbon steel fuel rack inserts were obtained from Midwest Precision Castings Company of O'Fallon, Missouri (see Appendix A). This foundry did not produce aluminum castings, therefore the estimate for the cast aluminum alloy was obtained from Production Patterns (San Liandro, California) ${ }^{\ddagger}$. Pricing estimates are compared below in Table 8. Note: these estimates do not include any finish machining costs. The Midwest Precision Castings estimate is based upon a production rate of 5 inserts per day; this rate could be tripled, if required.

For each Mark 1A fuel rack insert, the use of carbon steel (instead of $304 \mathrm{~L}$ stainless steel) results in a $\$ 75 \mathrm{~K}$ reduction of material costs, equivalent to a $13 \%$ cost reduction. The use of aluminum instead of stainless steel results in a $\$ 226 \mathrm{~K}$ reduction of material costs, a $40 \%$ cost reduction.

Table 8: Cost Quotes for Mark 1A Fuel Rack Insert

\begin{tabular}{||l|c|c|c|c|c||}
\hline \multicolumn{1}{|c|}{ Material } & $\begin{array}{c}\text { Initial } \\
\text { Tooling } \\
\text { Cost }\end{array}$ & $\begin{array}{c}\text { Per Unit } \\
\text { Material } \\
\text { Cost }\end{array}$ & $\begin{array}{c}\text { Total Cost } \\
\text { for 1000 } \\
\text { castings }\end{array}$ & $\begin{array}{c}\text { \$ Savings } \\
\text { vs. Stainless } \\
\text { Steel }\end{array}$ & $\begin{array}{c}\text { \% Savings } \\
\text { vs. Stainless } \\
\text { Steel }\end{array}$ \\
\hline $\begin{array}{l}\text { ASTM A743, CF-3 investment } \\
\text { cast stainless steel* }\end{array}$ & $\$ 8,000$ & $\$ 550$ & $\$ 558 \mathrm{~K}$ & --- & --- \\
\hline $\begin{array}{l}\text { ASTM A27, Grade 70-36 } \\
\text { investment cast carbon steel }\end{array}$ & $\$ 8,000$ & $\$ 475$ & $\$ 483 \mathrm{~K}$ & $\$ 75 \mathrm{~K}$ & $13 \%$ \\
\hline $\begin{array}{l}\text { ASTM B26, 356.0-T6 sand } \\
\text { cast aluminum }\end{array}$ & $\$ 7,000$ & $\$ 325$ & $\$ 332 \mathrm{~K}$ & $\$ 226 \mathrm{~K}$ & $40 \%$ \\
\hline
\end{tabular}

* material is similar to wrought 304L stainless steel (ASTM 1995A).

Also of interest are the machining costs associated with either the carbon steel or aluminum alloy in comparison to stainless steel. Once casting and heat treatment of the fuel rack insert is complete, finish machining will need to be performed to:

- size holes/cutouts for fuel rods, center post assembly, and outer support bars,

- turn inserts to obtain an accurate/consistent outer diameter, and

- clean up/flatten bottom of inserts (if necessary).

A comparison of recommended machining speeds is listed in Table 9. Slower cutting speeds result in larger per unit machining costs as both machine time and labor cost increases (increased tool wear at lower speeds is also a factor).

$\ddagger$ This is an oral quote from Jay St. John, Engineering, on March 5, 1997. 
Table 9: Recommended Machining Cutting Speeds (Oberg et al 1992)

\begin{tabular}{||l|l|c|c|c||}
\hline \multirow{2}{*}{\multicolumn{1}{|c|}{ Material }} & \multicolumn{1}{|c|}{$\begin{array}{c}\text { Material } \\
\text { Condition }\end{array}$} & \multicolumn{3}{|c|}{ Uncoated Carbide Cutting Speeds (ft/min) } \\
\cline { 3 - 5 } & & Turning & Drilling* & Reaming \\
\hline 304L Stainless Steel & Annealed & 225 & 55 & 150 \\
\hline 1020 cast steel & $\begin{array}{l}\text { As cast, annealed, } \\
\text { and normalized }\end{array}$ & 400 & 100 & 250 \\
\hline $\begin{array}{l}\text { All Aluminum Sand } \\
\text { Cast Alloys }\end{array}$ & $\begin{array}{l}\text { Solution treated } \\
\text { and aged }\end{array}$ & 1300 & 350 & 750 \\
\hline
\end{tabular}

* Drilling speeds are for high-strength steel tools.

A 1020 cast carbon steel has cutting speeds approximately twice those of the stainless steel; the cast aluminum alloys cutting speeds are five to six times faster. Based upon these numbers the greatest machining cost savings would be realized by using cast aluminum (two to three times the savings than with cast carbon steel). 
HNF-SD-SNF-ER-018

Revision 0

\subsection{CONCLUSIONS}

The A27 Grade 70-36 cast carbon steel has mechanical properties similar to the 304L stainless steel at the required temperatures. The B26 356.0-T6 cast aluminum alloy has similar room temperature properties. Elevated temperature properties are only about one-third that of the stainless steel, but are acceptable for the fuel rack insert's purpose. The aluminum thermal expansion coefficient is about double that of stainless steel; this could affect design tolerances and must be taken into consideration during final design.

The cast aluminum alloy is resistant to hydrogen up to its melting point. For the stated temperatures and hydrogen partial pressures, the cast carbon steel alloy has good corrosion resistance. Hydrogen attack or blistering are not expected and the effects of hydrogen embrittlement are acceptable.

Corrosion of the aluminum alloy is minimal during the short time period that the MCO is filled with water and during water removal. Accelerated galvanic corrosion of the cast carbon steel could be detrimental to the insert and may affect processing ability by clogging piping and/or filters with corrosion products.

Once the water is removed from the MCO, accelerated galvanic corrosion of either alloy ceases. Corrosion of either alloy by chlorine and iodine gas are not expected. Some high temperature oxidation (scaling) of the cast carbon steel is expected. The effects of liquid metal embrittlement by either cesium or tin are negligible. Radiation effects to the cast carbon steel are minimal; the cast aluminum will increase in strength with a small elongation reduction (this strength increase will aid in insert stability during hot conditioning).

Cost quotes for the cast aluminum showed a reduction of material costs by $40 \%$ in comparison to a cast stainless steel similar to wrought $304 \mathrm{~L}$. Substitution of the cast carbon steel would only reduce material costs by $13 \%$. Machining costs for aluminum are also less than that of carbon steel, both of which are less than stainless steel.

Based upon the better hydrogen and galvanic corrosion resistance and the lower material costs, the use of the B26 356.0-T6 sand cast aluminum is recommended over the A27 Grade 70-36 investment cast carbon steel as the Mark 1A fuel rack insert construction material. 


\subsection{REFERENCES}

Anantatmula, R. P. and R. P. Colburn, 1992, "Irradiation Corrosion of Waste Package Container Materials in Air/Steam Environment," Paper \#72, CORROSION92, Annual Conference and Corrosion Show Sponsored by NACE, Houston, Texas.

ASM, 1992, ASM Handbook, Volume 3 - Alloy Phase Diagrams, Tenth Edition, American Society for Metals, Metals Park, Ohio, pg. $2 \cdot 54$, and $2 \cdot 56$.

ASM, 1990, "Elevated-Temperature Properties of Ferritic Steels" in Metals Handbook, Volume IProperties and Selection: Irons, Steels, and High-Performance Alloys, Tenth Edition, American Society for Metals, Metals Park, Ohio, pg. 617-652.

ASM, 1985, Metals Handbook, Desk Edition, American Society for Metals, Metals Park, Ohjo.

ASM, 1984, Aluminum: Properties and Physical Metallurgy, J. E. Hatch Editor, American Society for Metals, Metals Park, Ohio.

ASME, 1995, Boiler \& Pressure Vessel Code, American Society of Mechanical Engineers, New York, New York.

ASTM, 1996, "Standard Specification for Aluminum-Alloy Sand Castings" in Annual Book of ASTM Standards, Specification B26-96, American Society for Testing and Materials, Philadelphia, Pennsylvania.

ASTM, 1995A, "Standard Specification for Castings, Iron-Chromium, Iron-Chromium-Nickel, Corrosion Resistant, for General Application" in Annual Book of ASTM Standards, Specification A743-95, American Society for Testing and Materials, Philadelphia, Pennsylvania.

ASTM, 1995B, "Standard Specification for Steel Castings, Carbon, for General Application" in Annual Book of ASTM Standards, Specification A27-95, American Society for Testing and Materials, Philadelphia, Pennsylvania.

Bailey, J. C., F. C. Porter, A. W. Pearson, and R. A. Jarman, 1994, "Aluminum and Aluminum Alloys" in Corrosion, Volume 1: Metal/Environment Reactions, Third Edition, L. L. Shreir, Editor, Butterworth Heinemann, Great Britain, pg. 4:3-4:37.

Berggren, R. G., 1965, "Radiation Properties" in ASME Handbook: Metals Engineering Design, Second Edition, O. J. Horger Editor, McGraw-Hill Book Company, New York, New York, pg. 403-417.

Berry, W. E., 1971, Corrosion in Nuclear Applications, John Wiley and Sons, Inc., New York, New York, pg. 411.

Blair, M., 1990, "Steel Castings" in Metals Handbook, Volume 1-Properties and Selection: Irons, Steels, and High-Performance Alloys, Tenth Edition, American Society for Metals, Metals Park, Ohio, pg. 363-379. 
Carlos, W. C. et al, 1994, Material Selection for Multi-Function Waste Tank Facility Tanks, WHC-SD-W236A-ES-003, Rev. 0, Westinghouse Hanford Company, Richland, Washington.

Chawla, S. L. and R. K. Gupta, 1993, Materials Selection for Corrosion Control, American Society for Metais, Materials Park, Ohio, pg 190.

Craig, B., 1987, "Hydrogen Damage" in Metals Handbook, Volume 13: Corrosion, Ninth Edition, American Society for Metals, Metals Park, Ohio, pg. 163-171.

DESH, 1997, K-Basin SNF Storage Basket Mock-Up Mark 1A, Rev. A, Duke Engineering and Services Hanford, Richland, Washington.

Emory, B. B., 1994, KE Basin Carbon Steel Corrosion, (internal memo, E8140-94-043, to W. F. Brehm, May 12, 1994), Westinghouse Hanford Company, Richland, Washington.

Garvin, L. J., 1997, Multi-Canister Overpack Topical Report, HNF-SD-SNF-SARR-005, Fluor Daniel Hanford, Richland, Washington.

Goldmann, L. H., 1996, Performance Specification for the Spent Nuclear Fuel Multi-Canister Overpack, WHC-S-0426, Revision 3, Westinghouse Hanford Company, Richland, Washington.

Graves, C. E., 1997, Evaluation of Carbon Steel for MCO Mark IV Fuel Basket Construction, HNF-SD-SNF-ER-017, Revision 0, Duke Engineering \& Services Hanford, Richland, Washington.

Hollingsworth, E. H., and H. Y. Hunsicker, 1987, "Corrosion of Aluminum and Aluminum Alloys" in Metals Handbook, Volume 13: Corrosion, Ninth Edition, American Society for Metals, Metals Park, Ohio, pg.583-609.

Kamdar, M. H., 1987, "Liquid-Metal Embrittlement" in Metals Handbook, Volume 13: Corrosion, Ninth Edition, American Society for Metals, Metals Park, Ohio, pg. 171- 184.

Kearney, A. L., 1990A, "Aluminum Foundry Products" in ASM Handbook, Volume 2 - Properties and Selection: Nonferrous Alloys and Special Purpose Materials, Tenth Edition, American Society for Metals, Metals Park, Ohio, pg.123-151.

Kearney, A. L., 1990B, Properties of Cast Aluminum Alloys" in ASM Handbook, Volume 2 - Properties and Selection: Nonferrous Alloys and Special Purpose Materials, Tenth Edition, American Society for Metals, Metals Park, Ohio, pg.152-177.

Lan, J. S. et al, 1996, Recent Dose Rate Calculational Summary for N-Reactor Fuel Handling and Shipping from K-Basin, WHC-SD-SNF-CAVR-001, Revision 0, Westinghouse Hanford Company, Richland, Washington.

Liening, E. L., 1987, "Corrosion by Chlorine" in Metals Handbook, Volume 13: Corrosion, Ninth Edition, American Society for Metals, Metals Park, Ohio, pg. 1170-1174.

Oberg, E. and F. D. Jones, H. L. Horton, and H. H. Ryffel, 1992, Machinery's Handbook, 24th Edition, Industrial Press, Inc., New York, New York, pg. 1007, 1008, 1010, 1029, 1030, and 1031. 
O'Neill, C. T., 1996A, Performance Specification for the K-Basin Spent Nuclear Fuel Hot Conditioning System Equipment, WHC-S-0460, Revision 1, Westinghouse Hanford Company, Richland, Washington.

O'Neill, C. T., 1996B, Performance Specification for the K-Basin Spent Nuclear Fuel Vacuum Drying Module, WHC-S-0435, Revision 0, Westinghouse Hanford Company, Richland, Washington.

Thurgood, M. J., 1997, Bounding Temperatures and Gas Generation Rates During CSB Staging, HNF-SD-SNF-CN-005, Revision 0, Fluor Daniel Hanford, Richland, Washington.

Vander Voort, G. F., 1990, "Embrittlement of Steels" in Metals Handbook, Volume I - Properties and Selection: Irons, Steels, and High-Performance Alloys, Tenth Edition, American Society for Metals, Metals Park, Ohio, pg. 689-736.

Weirick, L. J., 1987, "Corrosion of Uranium and Uranium Alloys" in Metals Handbook, Volume 13: Corrosion, Ninth Edition, American Society for Metals, Metals Park, Ohio, pg. 813-822.

WHC, 1996, Fabrication Specification for the Spent Nuclear Fuel Project Multi-Canister Overpack, WHC-S-0453, Rev. 0, Westinghouse Hanford Company, Richland, Washington. 
HNF-SD-SNF-ER-018

Revision 0

APPENDIX A - COST QUOTE

A-1 


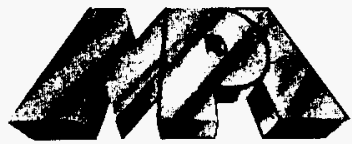

102 N. COOL SPRINGS ROAD

Revision 0

P. O. BOX 190 - O'FALLON, MO. 63366

PHONE 314-272-6190

FAX 314-272-3555

TO: Fluor Daniel Northwest

P.O. Box 1050, MSIN H5-70

DATE $\quad 3-4-97$

Richland, WA 99352-1050

ATTN: Carolyn Graves

$509 / 376-0279$ (FAX)

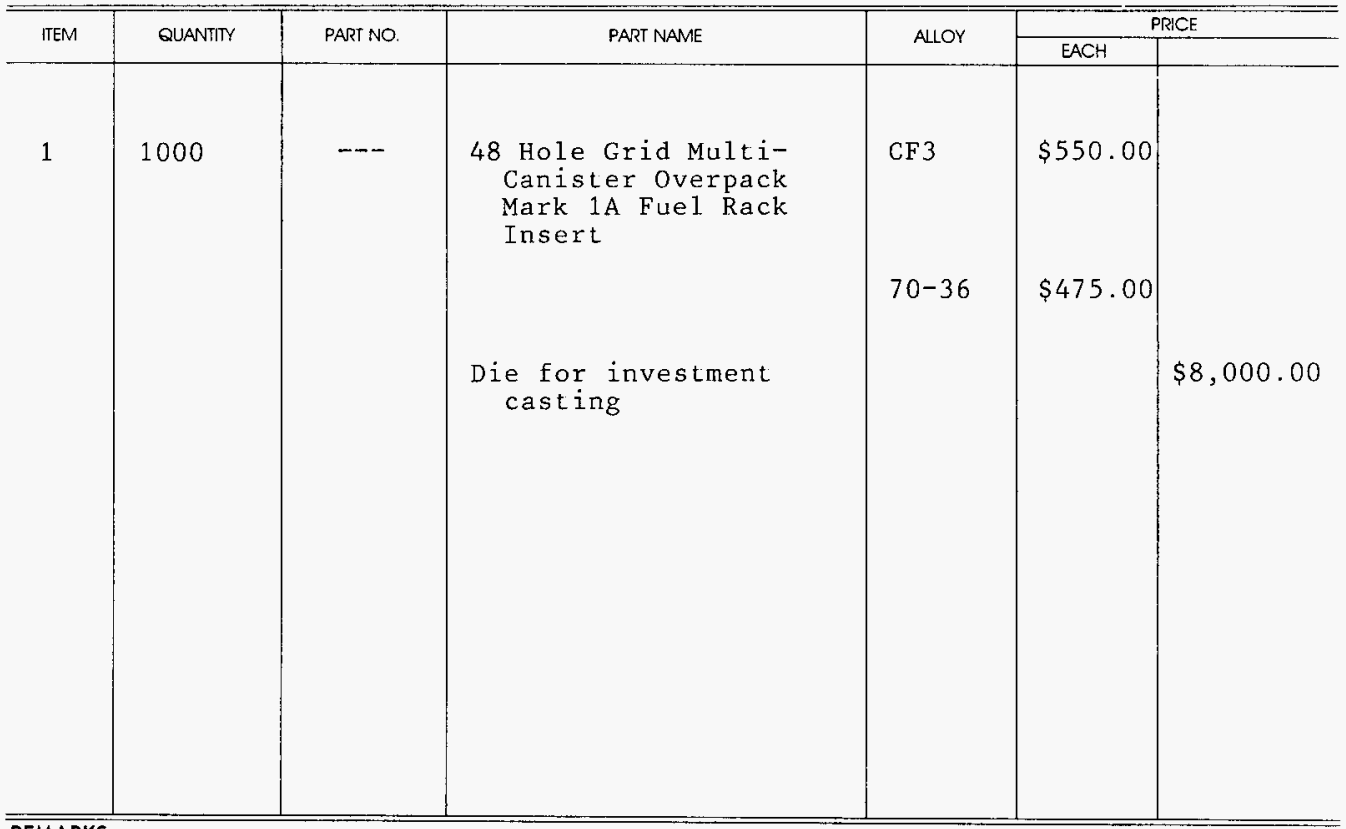

REMARKS:

We would be very comfortable at 5 parts per day. We can triple that if required.

- Please Furnish 3 Prints With Order-

MINIMUM SURFACE FINISH APPROX. 125 R.M.S. OR ALLOW FINISHING STOCK

CASTING TOLERANCE \pm .005 IN./IN. WITH MINIMUM TOLERANCE OF \pm .005 , OR ALLOW FINISHING STOCK.

F. O.B. O'FALION, MISSOURI

Delivery: Samples

8 weeks after receipt of order.

Production parts 8 weeks-as required after receipt of approval samples.

By

A-2

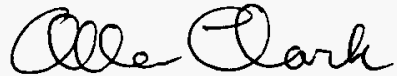

Allen Clark

Orders accepted are subject to terms and conditions on reverse side of this form. 


\section{DISTRIBUTION SHEET}

\begin{tabular}{|c|c|c|c|c|c|}
\hline \multirow{2}{*}{$\begin{array}{l}\text { To } \\
\text { Distribution }\end{array}$} & \multirow{2}{*}{\multicolumn{3}{|c|}{$\begin{array}{l}\text { From } \\
\text { Mechanisms Engneering, } \\
\text { Fluor Daniel Northwest }\end{array}$}} & \multicolumn{2}{|l|}{ Page 1 of 1} \\
\hline & & & & \multicolumn{2}{|c|}{ Date March 21, 1997} \\
\hline \multicolumn{4}{|c|}{ Project Title/Work Order } & \multicolumn{2}{|c|}{ EDT No. 604532} \\
\hline \multicolumn{4}{|c|}{$\begin{array}{l}\text { "Evaluation of Cast Carbon Steel and Aluminum for Rack Insert in } \\
\text { MCO Mark 1A Fuel Basket" HNF-SD-SNF-ER-018, Revision } 0\end{array}$} & \multicolumn{2}{|c|}{ ECN No. N/A } \\
\hline Name & MSIN & $\begin{array}{c}\text { Text } \\
\text { With All } \\
\text { Attach. }\end{array}$ & $\begin{array}{l}\text { Text } \\
\text { Only }\end{array}$ & $\begin{array}{c}\text { Attach./ } \\
\text { Appendix } \\
\text { Only }\end{array}$ & $\begin{array}{l}\text { EDT/ECN } \\
\text { Only }\end{array}$ \\
\hline
\end{tabular}

\section{Central Files (Org. +2)}

WC Alaconis

GD Bazinet

KH Bergsman

DM Chenault

RG Cowan

JI Diehl

DR Duncan

GL Edgemon

JR Frederickson

LH Goldmann

CE Graves (2)

JJ Irwin

AT Kee

M. Kummerer

BD Lorenz

CR Miska

RW Rasmussen

ES Ruff

RE Russell

EJ Shen

DA Smith

KE Smith

CE Swenson

JA Swenson

CA Thompson
A3-88 $X$

R3-85 X

B4-55 X

R3-48 X

R3-86 X

R3-86 X

X3-80 X

R3-86 $X$

RI-30 X

R3-86 X

R3-86 X

H5-70 X

H0-34 X

R3-86 X

A3-34 $\mathrm{X}$

R3-15 X

R3-86 X

R3-86 X

H5-70 X

H5-70 X

R3-86 X

R3-15 X

R3-86 X

S8-07 $X$

R3-11 $X$

R3-85 X 